\title{
Statistical Analysis of Compositional Data from Desmoinesian Sandstones in Oklahoma
}

\section{U.S. GEOLOGICAL SURVEY BULLETIN 1866-B}

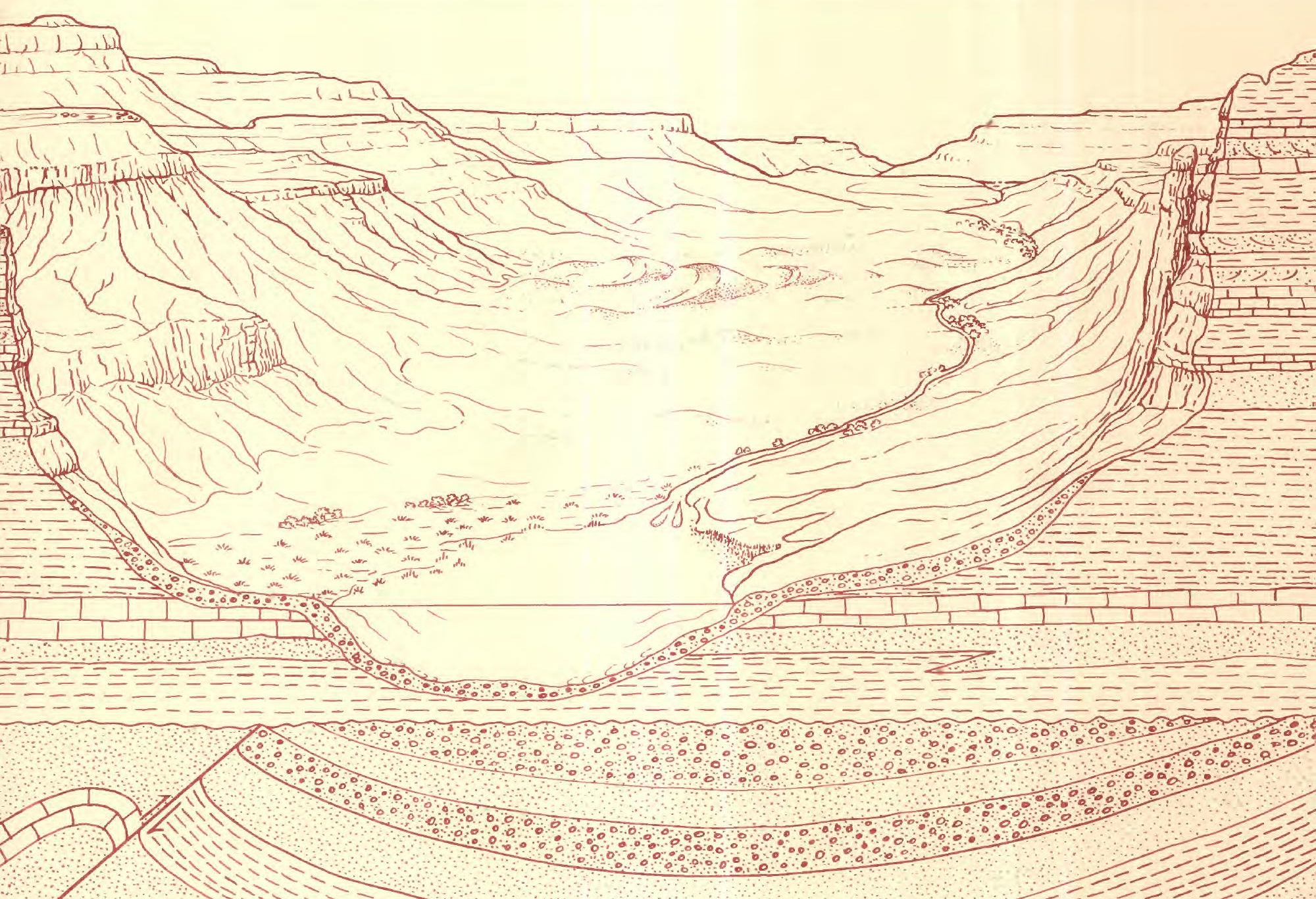




\section{AVAILABILITY OF BOOKS AND MAPS OF THE U.S. GEOLOGICAL SURVEY}

Instructions on ordering publications of the U.S. Geological Survey, along with prices of the last offerings, are given in the current-year issues of the monthly catalog "New Publications of the U.S. Geological Survey." Prices of available U.S. Geological Survey publications released prior to the current year are listed in the most recent annual "Price and Availability List." Publications that are listed in various U.S. Geological Survey catalogs (see back inside cover) but not listed in the most recent annual "Price and Availability List" are no longer available.

Prices of reports released to the open files are given in the listing "U.S. Geological Survey Open-File Reports," updated monthly, which is for sale in microfiche from the U.S. Geological Survey, Books and Open-File Reports Section, Federal Center, Box 25425, Denver, CO 80225 . Reports released through the NTIS may be obtained by writing to the National Technical Information Service, U.S. Department of Commerce, Springfield, VA 22161; please include NTIS report number with inquiry.

Order U.S. Geological Survey publications by mail or over the counter from the offices given below.

\section{BY MAIL}

\section{Books}

Professional Papers, Bulletins, Water-Supply Papers, Techniques of Water-Resources Investigations, Circulars, publications of general interest (such as leaflets, pamphlets, booklets), single copies of Earthquakes \& Volcanoes, Preliminary Determination of Epicenters, and some miscellaneous reports, including some of the foregoing series that have gone out of print at the Superintendent of Documents, are obtainable by mail from

\section{U.S. Geological Survey, Books and Open-File Reports Federal Center, Box 25425 Denver, CO 80225}

Subscriptions to periodicals (Earthquakes \& Volcanoes and Preliminary Determination of Epicenters) can be obtained ONLY from the

\section{Superintendent of Documents Government Printing Office Washington, D.C. 20402}

(Check or money order must be payable to Superintendent of Documents.)

\section{Maps}

For maps, address mail orders to

\section{U.S. Geological Survey, Map Distribution \\ Federal Center, Box 25286 \\ Denver, CO 80225}

Residents of Alaska may order maps from
Alaska Distribution Section, U.S. Geological Survey, New Federal Building - Box 12
101 Twelfth Ave., Fairbanks, AK 99701

\section{OVER THE COUNTER}

\section{Books}

Books of the U.S. Geological Survey are available over the counter at the following Geological Survey Public Inquiries Offices, all of which are authorized agents of the Superintendent of Documents:

- WASHINGTON, D.C.--Main Interior Bldg., 2600 corridor, 18th and C Sts., NW.

- DENVER, Colorado--Federal Bldg., Rm. 169, 1961 Stout St.

- LOS ANGELES, California--Federal Rldg., Rm. 7638, 300 N. Los Angeles St.

- MENLO PARK, California--Bldg. 3 (Stop 533), Rm. 3128 , 345 Middlefield Rd.

- RESTON, Virginia--503 National Center, Rm. 1C402, 12201 Sunrise Valley Dr.

- SALT LAKE CITY, Utah--Federal Bldg., Rm. 8105, 125 South State St.

- SAN FRANCISCO, California--Customhouse, Rm. 504, 555 Battery St.

- SPOKANE, Washington--U.S. Courthouse, Rm. 678, West 920 Riverside Ave..

- ANCHORAGE, Alaska--Rm. 101, 4230 University Dr.

- ANCHORAGE, Alaska--Federal Bldg, Rm. E-146, 701 C St.

\section{Maps}

Maps may be purchased over the counter at the U.S. Geological Survey offices where books are sold (all addresses in above list) and at the following Geological Survey offices:

- ROLLA, Missouri--1400 Independence Rd.

- DENVER, Colorado--Map Distribution, Bldg. 810, Federal Center

- FAIRBANKS, Alaska--New Federal Bldg., 101 Twelfth Ave. 
Chapter B

\section{Statistical Analysis of Compositional Data from Desmoinesian Sandstones in Oklahoma}

\section{By THADDEUS S. DYMAN}

A multidisciplinary approach to research studies of sedimentary rocks and their constituents and the evolution of sedimentary basins, both ancient and modern

U.S. GEOLOGICAL SURVEY BULLETIN 1866

EVOLUTION OF SEDIMENTARY BASINS-ANADARKO BASIN 


\title{
DEPARTMENT OF THE INTERIOR MANUEL LUJAN, JR., Secretary
}

\author{
U.S. GEOLOGICAL SURVEY
}

Dallas L. Peck, Director

Any use of trade, product, or firm names in this publication is for descriptive
purposes only and does not imply endorsement by the U.S. Government.

UNITED STATES GOVERNMENT PRINTING OFFICE: 1989

For sale by the

Books and Open-File Reports Section

U.S. Geological Survey

Federal Center

Box 25425

Denver, CO 80225

\section{Library of Congress Cataloging-in-Publication Data}

Dyman, T. S.

Statistical analysis of compositional data from Desmoinesian sandstones in Oklahoma / by Thaddeus S. Dyman.

p. $\quad \mathrm{cm}$. - (Evolution of sedimentary basins-Anadarko Basin; ch.

B) (U.S. Geological Survey bulletin ; 1866-B)

"A multidisciplinary approach to research studies of sedimentary rocks and their constituents and the evolution of sedimentary basins, both ancient and modern."

Bibliography: $p$.

Supt. of Docs. no.: | 19.3: 1866-B

1. Sandstone-Oklahoma-Composition. 2. Petrology-Statistical methods. I. Title. II. Series. III. Series: U.S. Geological Survey bulletin ; 1866-B.

QE75.B9

[QE471.15.S25]

$557.3 \mathrm{~s}-\mathrm{dc} 20$

[5521.5] 


\section{CONTENTS}

Abstract B1
Introduction B1
Regional geology B2
Regional stratigraphy and sedimentology
Method of study B3
Statistical analysis of compositional data
R-mode analysis B4
Q-mode analysis B6
Petrofacies I B6
Petrofacies II $\quad$ B6
Petrofacies III $\quad$ B7
Petrofacies IV $\quad$ B8
Factor-score maps B8
Paleogeographic implications B10
Summary B11
References cited B12

\section{FIGURES}

1. Map showing major structural features of Oklahoma during Pennsylvanian time $\quad \mathbf{B 2}$

2. Chart showing generalized stratigraphy for Desmoinesian sandstones, Arkoma basin and northern Oklahoma platform B3

3. Map showing sample localities for this study B4

4. Weighted pair-group average dendrogram of framework grains for Desmoinesian sandstones B7

5-9. Photographs showing:

5. Petrofacies I sandstone, sample 24-1 B8

6. Petrofacies II sandstone, sample 13-2 B8

7. Petrofacies III sandstone, sample 17-1 B8

8. Petrofacies IV sandstone, sample 81-1 B9

9. Petrofacies IV sandstone, sample 91-1 B9

10-12. Correspondence analysis factor-score maps for:
10. Factors 1 and 2
B9
11. Factors 3 and 4
B10
12. Factors 2 and 4 B10

13. Plot showing total quartz-total feldspar-total lithics compositions of Desmoinesian sandstones in study B11

\section{TABLES}

1. Absolute variable-factor contribution matrix (first four factors) and cumulative percent contribution for ten original framework grain variables

2. Petrofacies summary for Desmoinesian sandstones in this study 
CONVERSION FACTORS FOR SOME SI METRIC AND U.S. UNITS OF MEASURE

\begin{tabular}{lll}
\hline \multicolumn{1}{c}{ To convert from } & \multicolumn{1}{c}{ To } & \multicolumn{1}{c}{ Multiply by } \\
\hline Feet $(\mathrm{ft})$ & Meters $(\mathrm{m})$ & 0.3048 \\
Miles $(\mathrm{mi})$ & Kilometers $(\mathrm{km})$ & 1.609 \\
Pounds $(\mathrm{lb})$ & Kilograms $(\mathrm{kg})$ & 0.4536 \\
Degrees Fahrenheit $\left({ }^{\circ} \mathrm{F}\right)$ & Degrees Celsius $\left({ }^{\circ} \mathrm{C}\right)$ & Temp ${ }^{\circ} \mathrm{C}=\left(\right.$ temp $\left.{ }^{\circ} \mathrm{F}-32\right) / 1.8$ \\
\hline
\end{tabular}




\title{
Statistical Analysis of Compositional Data from Desmoinesian Sandstones in Oklahoma
}

\author{
By Thaddeus S. Dyman
}

\section{Abstract}

Desmoinesian sandstones from the northern Oklahoma platform and the Anadarko, Arkoma, and Ardmore basins record a complex interaction between mid-Pennsylvanian source-area tectonism and cyclic sedimentation patterns associated with numerous transgressions and regressions. Framework-grain summaries for 50 thin sections from sandstones of the Krebs, Cabaniss, and Marmaton Groups and their surface and subsurface equivalents were subjected to multivariate statistical analyses to establish regional compositional trends for provenance analysis.

R-mode cluster and correspondence analyses were used to determine the contributing effect (total variance) of key framework grains. Fragments of monocrystalline and polycrystalline quartz, potassium and plagioclase feldspar, chert, and metamorphic, limestone and mudstonesandstone rock fragments contribute most to the variation in the grain population. Q-mode cluster and correspondence analyses were used to identify four petrofacies and establish the range of compositional variation in Desmoinesian sandstones. Petrofacies $\mathrm{I}$ is rich in monocrystalline quartz (78-98 percent); mica and rock fragments are rare. Petrofacies II is also rich in monocrystalline quartz (60-84 percent) and averages 12 percent total rock fragments. Petrofacies III and IV are compositionally heterogeneous and contain variable amounts of monocrystalline and polycrystalline quartz, potassium feldspar, mica and chert, and metamorphic and sedimentary rock fragments.

Quantitative analyses indicate that Desmoinesian sandstones were derived from sedimentary, igneous, and metamorphic source areas. Petrofacies I and II sandstones occur predominantly in the lower Desmoinesian and are widely distributed, although they are most abundant in eastern and central Oklahoma; sandstones from petrofacies III and IV are widely distributed and occur primarily in the middle and upper Desmoinesian. The range of

Manuscript approved for publication, April 11, 1989. compositional variation and the distribution of petrofacies are related to paleotectonics and basin development, sediment recycling, and varying depositional environments.

\section{INTRODUCTION}

The present-day geologic framework of Oklahoma and the entire southern midcontinent region is related directly to Pennsylvanian paleotectonic development (fig. 1). Source-area variability and multiple marine transgressions and regressions have resulted in abrupt facies changes and complex depositional cycles. Many published studies have reconstructed Pennsylvanian paleogeography by using stratigraphic and sedimentologic data within these depositional cycles, but detailed petrologic studies are rare. Published compositional data for sandstones are generally limited to field or core rock descriptions and are not detailed enough for provenance studies. Quantitative analysis of existing data is difficult.

Desmoinesian sandstones in Oklahoma record a complex interaction between source-area tectonism, regional transgression, and sediment recycling. These sandstones are readily identifiable in both outcrop and core and exhibit much compositional heterogeneity. Studies to better understand compositional variations in these sandstones may aid in paleogeographic reconstruction and stratigraphic correlation, especially where nomenclature is confusing. These studies may be valuable because of the significant oil and gas potential of Desmoinesian strata in Oklahoma.

A quantitative petrographic analysis of Desmoinesian sandstones was conducted in order to: (1) define sandstone petrofacies for regional correlation and determine which framework grains contribute the most to variations in sandstone composition; (2) describe lateral and vertical variations in source area in order to add to the sedimentary-tectonic framework for the 


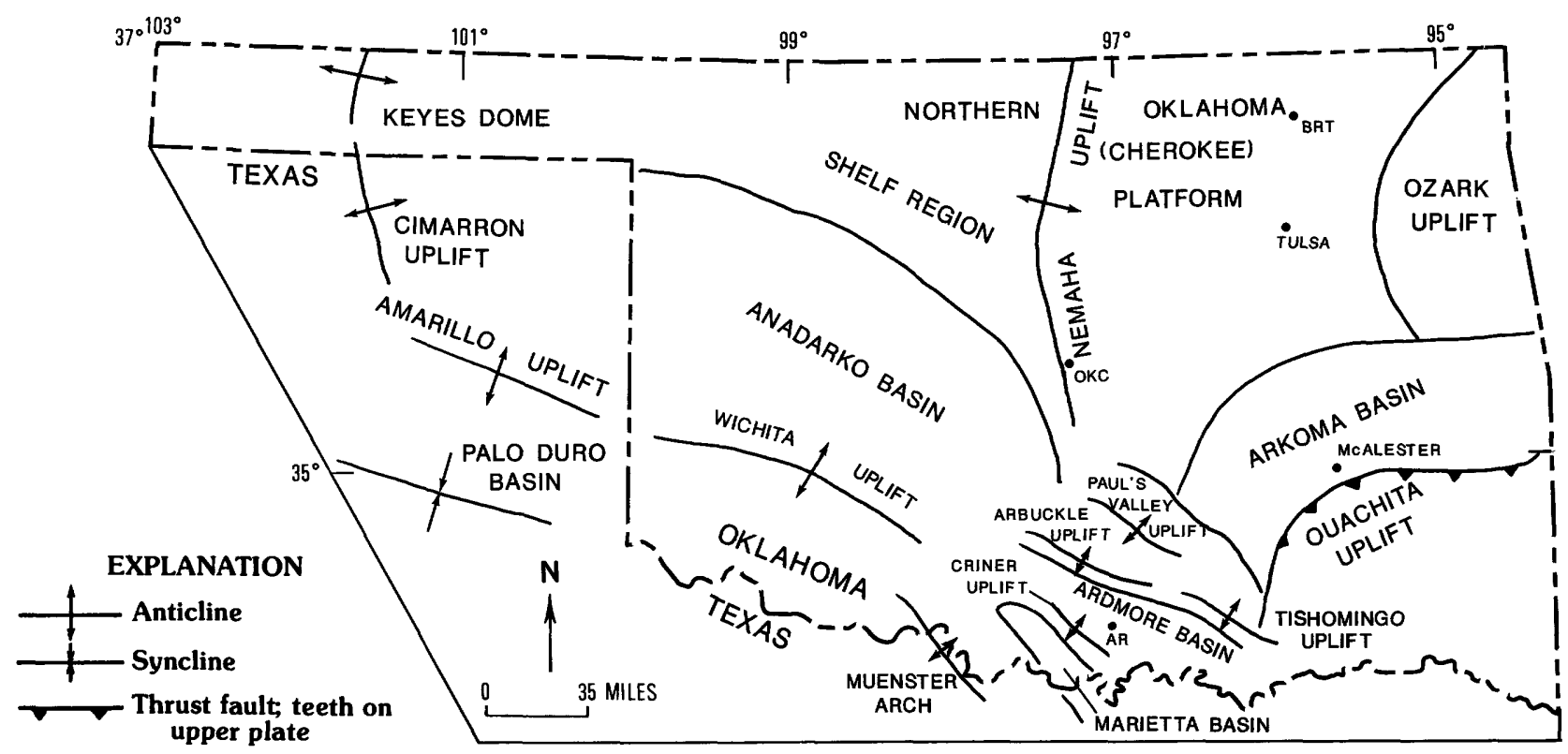

Figure 1. Major structural features of Oklahoma during Pennsylvanian time. OKC, Oklahoma City; AR, Ardmore; BRT, Bartlesville. Data from Jordan (1961), Branson (1961), Johnson (1971), Frezon and Dixon (1975), and Krumme (1981).

Desmoinesian in the region; and (3) determine the usefulness of statistical analyses in petrographic studies. The most important goal of this study was to simply define the range of compositional variation in sandstones. The petrographic database exhibits much variation, and because variations in the sample population were difficult to define subjectively, a statistical approach was undertaken.

This study is preliminary and is intended to establish a base for future quantitative petrographic studies. The compositional range of Desmoinesian sandstones may be expanded in the future as more sandstones are analyzed. Additional sandstones must be compositionally and sedimentologically analyzed before a thorough understanding of Pennsylvanian paleogeography is attained. Any final provenance determination should be based on stratigraphic, sedimentologic, and petrologic data.

Core samples were obtained from the Oklahoma Geological Survey Core and Sample Library. This report was prepared for the U.S. Geological Survey Evolution of Sedimentary Basins Program.

\section{REGIONAL GEOLOGY}

The geography of Oklahoma and the surrounding region during the Pennsylvanian was strongly affected by the Ouachita orogeny, the result of a collision of North America with South America and Africa (Kluth and Coney, 1981). Regional structural elements active during the Pennsylvanian are shown in figure 1. The AmarilloWichita-Criner uplift was a prominent structural feature throughout most of the Pennsylvanian and extended for more than $300 \mathrm{mi}$ from the Texas Panhandle southeastward into southern Oklahoma. The Muenster arch is a southern extension of the Wichita-Criner trend but is separated from the Criner uplift by the Marietta basin (Frezon and Dixon, 1975). The Cimarron uplift and Keyes dome form a northward extension of the Amarillo uplift in the Oklahoma Panhandle.

The Nemaha uplift is a prominent subsurface structural feature that trends from south of Oklahoma City northward for more than $400 \mathrm{mi}$ into Nebraska (Luza, 1978). The axis of this feature represents the highest part of a more extensive Early Pennsylvanian positive area often referred to as the Nemaha highlands.

The Anadarko basin is bordered by the Nemaha uplift to the northeast, the central Kansas shelf to the north, and the Amarillo-Wichita-Criner trend to the south. It is one of the deepest cratonic basins in North America and contains more than $40,000 \mathrm{ft}$ of Cambrian through Permian sedimentary rocks along its southern margin. More than $20,000 \mathrm{ft}$ of stratigraphic separation exists along the Wichita megashear in southwestern Oklahoma (Evans, 1979).

During Desmoinesian time, the southern part of the Ouachita geosyncline in southeastern Oklahoma was uplifted by thrusting and folding and a prominent positive feature known as the Ouachita uplift developed. The northern part of the geosyncline and a shelf region to the north retained a basinal configuration and are together referred to as the Arkoma basin (Branson, 1961). The Arbuckle and Paul's Valley uplifts were positive elements in south-central Oklahoma during Desmoinesian and Missourian time. The Ardmore basin contains 
almost 20,000 $\mathrm{ft}$ of Upper Mississippian and Pennsylvanian strata and is separated from the Anadarko basin by local uplifts (Jacobson, 1959).

The Ozark uplift in northeastern Oklahoma and Missouri is an earlier Paleozoic structural feature that was rejuvenated during the mid-Pennsylvanian at approximately the same time as the Ouachita uplift (Branson, 1961; Frezon and Dixon, 1975).

\section{REGIONAL STRATIGRAPHY AND SEDIMENTOLOGY}

Stratigraphic names for outcrop and core samples of sandstones are from published reports and summaries prepared by well-site geologists. Stratigraphic nomenclature in Oklahoma is confusing in part because of facies differences between platform and basin and in part by historic differences in surface and subsurface nomenclature (Krumme, 1981). Figure 2 illustrates Desmoinesian sandstone nomenclature for the State compiled from Jordan (1957), Tomlinson and McBee (1959), Branson (1961), Frezon and Dixon (1975), Ebanks (1979), Krumme (1981), and Sutherland (1982). Limestone and shale units not addressed in this report have been omitted from the figure. Informal subsurface stratigraphic names have also been omitted from figure 2 because of the uncertainty of precisely correlating them with surface units.

Desmoinesian formations are divided into three groups, from oldest to youngest, the Krebs, Cabaniss, and Marmaton (Krumme, 1981). These groups and their stratigraphic equivalents are bounded by unconformities and are found throughout Oklahoma. In the Ardmore and eastern Anadarko basins, equivalent strata are included in the Deese Formation. In western Oklahoma, the Krebs and Cabaniss Groups are informally referred to as the Cherokee Group or are left as undivided Desmoinesian strata (Frezon and Dixon, 1975). The term Cherokee Group is generally not accepted in Oklahoma (Ebanks, 1979).

The oldest Desmoinesian formation in central and eastern Oklahoma, the Hartshorne Sandstone, rests unconformably on older Atokan or pre-Pennsylvanian strata. The overlying McAlester Formation is predominantly shale but contains one regionally persistent sandstone referred to as the Warner Sandstone Member and its informal subsurface equivalent the Booch sandstone. The Savanna Formation unconformably overlies the McAlester Formation in the Arkoma basin and contains many discontinuous sandstone and coal beds. The base of the overlying Boggy Formation is drawn at the base of the Bluejacket Sandstone Member and its informal subsurface equivalent, the Bartlesville sandstone (Branson, 1961). Informal subsurface sandstone equivalents of the upper

\begin{tabular}{|c|c|c|}
\hline$\frac{\stackrel{m}{\frac{m}{\alpha}}}{\frac{w}{\infty}}$ & $\begin{array}{l}\stackrel{0}{2} \\
\stackrel{0}{0} \\
0\end{array}$ & FORMATION AND MEMBER \\
\hline \multirow{3}{*}{ 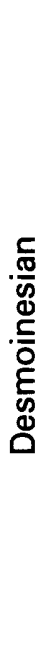 } & 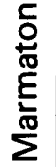 & $\begin{array}{l}\text { Upper Marmaton Group sandstones } \\
\text { Labette Shale } \\
\text { Calvin Sandstone }\end{array}$ \\
\hline & 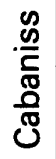 & $\begin{array}{l}\text { Senora Formation } \\
\text { Chelsea Sandstone Member } \\
\text { Thurman Sandstone }\end{array}$ \\
\hline & 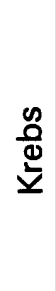 & $\begin{array}{l}\text { Boggy Formation } \\
\quad \text { Taft Sandstone Member } \\
\quad \text { Bluejacket Sandstone Member } \\
\text { Savanna Formation sandstones } \\
\text { McAlester Formation } \\
\quad \text { Warner Sandstone Member } \\
\text { Hartshorne Sandstone }\end{array}$ \\
\hline
\end{tabular}

Figure 2. Generalized stratigraphy for Desmoinesian sandstones, Arkoma basin and northern Oklahoma platform. Informal subsurface names have been omitted from the chart because of the discontinuous nature of Pennsylvanian sandstones and the difficulty of correlating surface with subsurface units. Chart is incomplete because only stratigraphic names addressed in this report are included. Deese Formation of south-central Oklahoma includes strata equivalent to the three groups identified here. Data from Jordan (1957), Tomlinson and McBee (1959), Branson (1961), Frezon and Dixon (1975), Ebanks (1979), Krumme (1981), and Sutherland (1982).

part of the Boggy (Taft Sandstone Member) include the Red Fork and Burbank sandstones.

The Thurman Sandstone unconformably overlies shales in the upper Boggy in southern Oklahoma but is absent on the northern Oklahoma platform. The overlying Senora Formation is laterally persistent but lithologically variable. The Chelsea Sandstone Member is locally present in eastern Oklahoma. The Skinner sandstone is an informal subsurface equivalent of the Senora Formation (Krumme, 1981).

The upper Desmoinesian Marmaton Group is composed primarily of shale, sandstone, and limestone. In the Arkoma basin, the Calvin Sandstone forms the base of the group but is replaced by the Fort Scott Limestone on the northern Oklahoma platform. The informal Prue sandstone may represent a lateral shelf equivalent of the Calvin. The overlying Peru sandstone is part of the Labette Shale (Krumme, 1981). Sandstones in the upper Marmaton Group, such as the informal Cleveland sandstone, are interbedded with shale and are often discontinuous. 
Sedimentologically, Desmoinesian sandstones were deposited in fluvial, deltaic, and marine depositional environments associated with the Early Pennsylvanian northward transgression. During the early Desmoinesian, fluvial, deltaic, and shallow-marine depositional environments dominated the northern Oklahoma shelf, whereas deeper water marine environments dominated the southern Anadarko and Ardmore basins. With a presumed southward shift in provenance (Krumme, 1981), marine carbonate shelf sedimentation dominated northern Oklahoma during the late Desmoinesian. Coarse-grained alluvial sediments were deposited along the margins of uplifts. Paleoenvironments may vary from these regional trends because of local source-area influence and sea level changes. Most of the sandstones analyzed in this report were deposited in deltaic and shallow-marine environments. Compositional variations are considered to be due primarily to different source areas; however, compositional modification due to changing depositional environments cannot be totally discounted until a thorough provenance study has been completed.

\section{METHOD OF STUDY}

The study includes core and outcrop samples on the northern Oklahoma platform, both east and west of the Nemaha uplift, and in the Anadarko, Arkoma, and Ardmore basins in both western and southeastern Oklahoma (figs. 1, 3). Fifty medium-grained sandstone samples were cut, thin sectioned, stained for potassium feldspar, and point counted. More than 300 grains were counted per slide. Quartz grains were examined for extinction patterns, inclusions, and overgrowths (Folk, 1968). Accessory minerals such as micas, hornblende, garnet, and zircon were identified as either present or absent. Compositional variations due to differential weathering of surface versus subsurface samples were not addressed in the statistical analysis. These variations are considered minor in this population of sandstones.

Sample location and composition data for all samples in this study are given in Dyman (1987). Data were aggregated according to methods presented in Dickinson and Suczek (1979).

\section{STATISTICAL ANALYSIS OF COMPOSITIONAL DATA}

The following statistical procedure was used in this study. (1) R-mode correspondence analysis was used to determine the contributing effect (percentage of total variance) of each framework grain type (variable). Based on their contributing effect, variables were then aggregated into genetic groups. (2) Q-mode cluster analysis and correspondence analysis were then used to determine sample relationships and the range of compositional variation. Samples were aggregated into petrofacies groups to analyze stratigraphic and geographic variations in sandstone composition.

Correspondence analysis is a form of factor analysis that combines the results of both Q- and R-mode studies and reduces variable scaling problems. It reduces the problem of $\mathrm{N}$-dimensional space (many variables) by projecting combinations of original variables on a new set

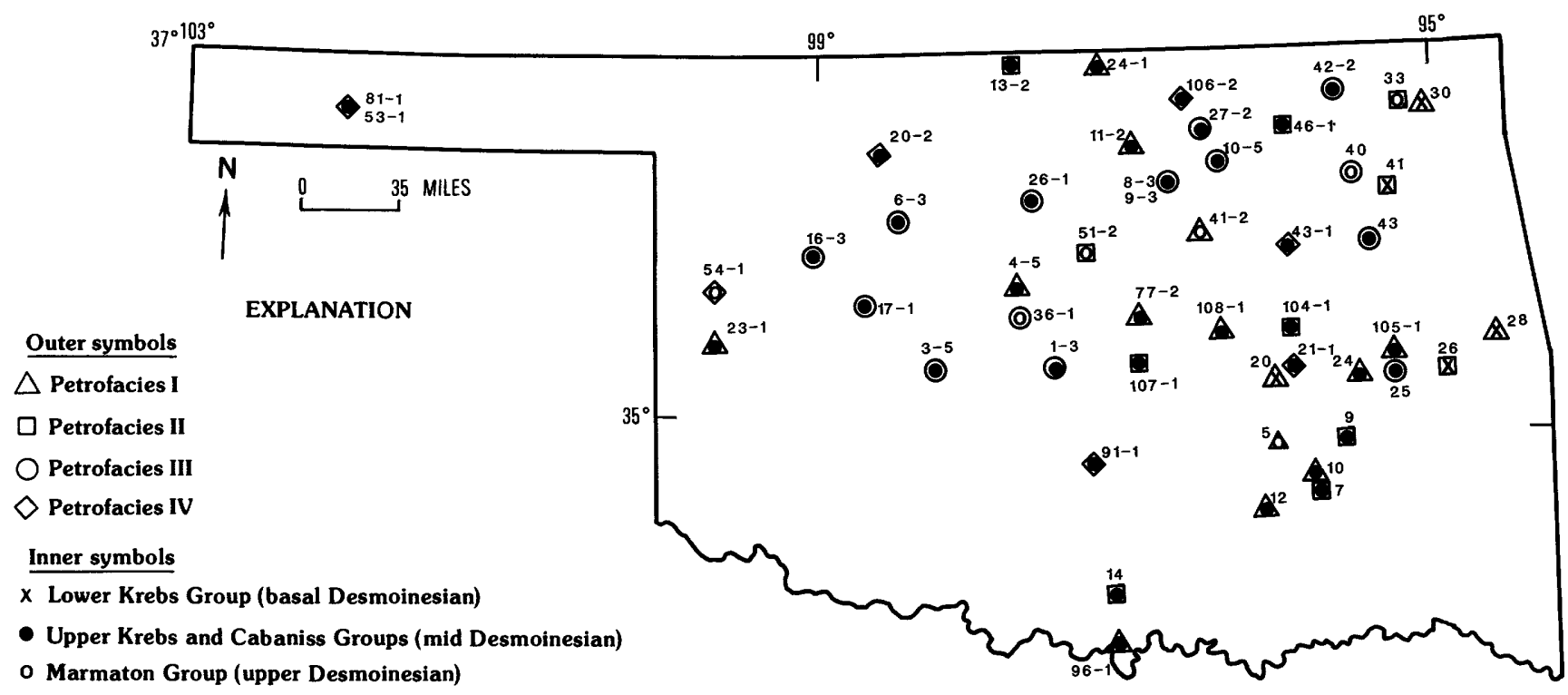

Figure 3. Sample localities for this study. Detailed geographic and compositional data for all samples given in Dyman (1987). 
of axes (eigenvectors) that define new hypothetical variables called factors (David and others, 1977). Variable contribution on the new set of axes is based on variance. Data standardization to reduce problems induced by varying magnitude is not required. Data are transformed into conditional probabilities by dividing each data element by the sum of all elements.

Output from correspondence analysis includes: (1) relative and absolute factor-variable contribution matrices that define the relative or absolute contribution of each original variable (as a percent) to each new factor (that is, which variables are important in distinguishing all samples together); (2) a factor-score data matrix that contains factor-score loadings (that is, which variables are important in distinguishing each sample from other samples); and (3) factor-score maps (plots) created from the factor-score matrix that graphically display sample similarity in factor space. Lines are drawn on each plot to illustrate how each numbered variable contributes to differences among samples. The lines pass through a portion of factor space defined by their R-mode loadings. The lines represent the strength and direction according to which the different variables affect the sample population (David and others, 1974). The lines intersect at a point representing the average composition of the sandstones. The proximity of a group of sample points near a variable line (or lines) illustrates the similarity of samples and the variable (or variables) responsible for the similarity. Closely spaced sample points on one factor-score plot (for example, a plot of factors 1 and 2) may not occur together on a plot of different factors (for example, factors 3 and 4) because of the difference in variable contribution to different factors.

Cluster analysis is a multivariate classification method by which relatively homogeneous groups are defined by assigning samples to a group based on their similarity. A dendrogram defining all of the groups is created by the computer program (Davis, 1973, 1986). In hierarchical clustering, the most similar samples are joined in a cluster that then successively joins with other clusters until all samples are included in the dendrogram. Modal analyses for Desmoinesian sandstones were first standardized by using the variable-mean deviation to insure that each variable was weighted equally.

The weighted pair-group clustering program of Davis was used with the r-correlation coefficient in this study. Cluster dendrograms produced with distance coefficients may include well-defined cluster groups even if some samples are very dissimilar from other samples. In this study, cluster dendrograms were generated separately with distance and r-correlation coefficients and provided similar results.

In the weighted pair-group cluster method, correlation matrices of samples are calculated and samples having high correlations are extracted. In subsequent steps, similarity matrices are recomputed; clustered elements are treated as a single element. Each new cluster member is given equal weight with the existing cluster. Thus, late cluster arrivals carry more weight than do earlier arrivals.

Several alternative clustering methods are available (Davis, 1986), and determining the best clustering method may depend on the specific data set. Davis (1986) suggested that the weighted pair-group method provides the best results but that researchers should compare different methods. In this study, the results from cluster analysis were corroborated using correspondence analysis.

\section{R-Mode Analysis}

Table 1 shows the absolute variable-factor contribution matrix for the 10 framework grain types analyzed in this study. Sandstone, siltstone, and mudstone grains (mudstone-sandstone in table 1) were combined for the statistical analysis. Dark-gray to brown, siliceous and calcareous mudstone and shale are the most abundant of these grain types. In some cases, it was difficult to differentiate between weakly foliated metamorphic grains and shale grains. Together, the first four factors contribute 85 percent to the variation in the total sample of framework grains. The most important variables are for factor 1 , potassium feldspar (92 percent); for factor 2, monocrystalline quartz (22 percent), limestone grains (19 percent), polycrystalline quartz (16 percent), metamorphic rock grains (15 percent), plagioclase (11 percent), and chert (10 percent); for factor 3 , limestone grains (76 percent); and for factor 4, metamorphic rock grains (43 percent), mudstone-sandstone grains (29 percent), and chert (18 percent). Volcanic and mica grains contribute less to the total variation in the sample population than do the other variables.

Factor 1 is controlled primarily by the high loading for potassium feldspar due to the two samples from the Cherokee Group in the Oklahoma Panhandle (samples 53-1 and 81-1). The high loading for limestone in factor 3 is due to limestone-rich samples from northern and southern Oklahoma (samples 91-1 and 20-2). Samples rich in variables with high loadings for factor 2 are widely distributed in Oklahoma in part because of the many grain types contributing to factor 2 . Factors 3 and 4 are controlled primarily by chert and lithic grains from middle and upper Desmoinesian samples.

When the correspondence analysis was rerun without the potassium feldspar- and limestone-rich samples, cumulative variation was distributed proportionally according to the relative importance of the remaining variables. Monocrystalline and polycrystalline quartz, mudstone-sandstone, and metamorphic grains contributed more to each factor. 
Table 1. Absolute variable-factor contribution matrix (first four factors) and cumulative percent contribution for ten original framework grain variables

\begin{tabular}{lrrrr}
\hline Grain type & \multicolumn{3}{c}{ Factor } & \multicolumn{1}{c}{3} \\
\hline Monocrystalline quartz & 1.2 & 22.4 & 2.9 & 0.1 \\
Polycrystalline quartz & .8 & 16.4 & 2.3 & 2.0 \\
Chert & .1 & 10.4 & 1.5 & 17.6 \\
Plagioclase & 2.9 & 10.8 & 1.6 & .1 \\
Potassium feldspar & 92.0 & .3 & .6 & 1.2 \\
Mudstone-sandstone & .2 & 4.2 & 7.9 & 28.8 \\
Limestone & .7 & 19.1 & 76.1 & .4 \\
Volcanic & .1 & .2 & .1 & 4.9 \\
Metamorphic & 1.7 & 15.0 & 5.0 & 42.8 \\
Mica & .2 & .9 & 1.6 & 2.1 \\
$\quad$ Cumulative percent contribution & 41 & 60 & 77 & 85 \\
\hline
\end{tabular}

Quartz, chert, potassium and plagioclase feldspar, and limestone, mudstone-sandstone, and metamorphic grains contribute the most to variation in this population of Desmoinesian sandstones.

\section{Q-Mode Analysis}

Four petrofacies groups were identified for 50 sandstone samples by using cluster analysis. Figure 4 illustrates the weighied pair-group dendrogram and petrofacies groups using all 10 original framework variables. Petrofacies subdivision based on clustering procedures is somewhat arbitrary, especially if cluster groups join at low levels of similarity. Additional cluster groups can be defined depending on the level of compositional similarity we wish to establish in the sample population. Table 2 summarizes the characteristics of each petrofacies defined in this study. Petrofacies differences are based on compositional variations in framework grains. Quartz extinction patterns and the presence or absence of accessory minerals do not significantly vary between samples and were not used to differentiate sandstones.

The geographic distribution of petrofacies for lower, middle, and upper Desmoinesian sandstones is presented in figure 3. For the purpose of this study, lower Desmoinesian includes only the lower part of the Krebs (Hartshorne Sandstone and the Warner Sandstone Member of the McAlester Formation; middle Desmoinesian includes the upper part of the Krebs (Savanna and Boggy sandstones) and Cabaniss Groups; and upper Desmoinesian includes sandstones in the Marmaton Group. This subdivision is arbitrary and is meant only to address gross compositional variations in Desmoinesian strata. The subdivision also alleviates some of the correlation problems introduced when comparing informal subsurface with surface nomenclature. Future studies including more samples could define additional or different stratigraphic groups.

\section{Petrofacies I}

Petrofacies $I$ is subdivided into two petrofacies subgroups and is rich in monocrystalline quartz (mean 84 percent) (fig. 5). Subgroup A contains an average of 88 percent monocrystalline quartz, whereas subgroup B contains 80 percent. Polycrystalline quartz averages only 5 percent for petrofacies I. Lithic grains are rare or absent in subgroup $A$ and reach a maximum value of 14 percent for subgroup B (sample 11-2, Red Fork sandstone, northern Oklahoma; fig. 3). Metamorphic grains are more abundant than sedimentary grains for both subgroups but are most abundant in subgroup B. Feldspar is rare or absent in both subgroups.

Petrofacies I is widely distributed throughout the study area especially along a north-trending belt in part coinciding with the axis of the Nemaha uplift. Stratigraphically, all three groups of Desmoinesian age are represented in petrofacies I, but most samples are from the lower and middle Desmoinesian. No relationship appears to exist between stratigraphic group assignment and geographic distribution. Both upper Desmoinesian petrofacies I samples (sample 5, Senora Formation, and sample 41-2, Prue sandstone; fig. 3) are in subgroup A and contain an average of more than 90 percent total quartz.

\section{Petrofacies II}

Petrofacies II contains less monocrystalline quartz (mean 75 percent) and more chert (mean 8 percent) and polycrystalline quartz (mean, 10 percent) than petrofacies I (fig. 6). It is more compositionally heterogeneous than petrofacies I and averages 12 percent total lithic grains (including chert) and 2 percent feldspar. Sample 46-1 (Bartlesville sandstone) is not representative of petrofacies II (fig. 4) and contains only 70 percent total quartz. Its presence in petrofacies II is probably an artifact of the clustering method. 
CORRELATION COEFFICIENT

$\begin{array}{lllll}0.5 & 0.6 & 0.7 & 0.8 & 0.9\end{array}$

$\begin{array}{lllll}1 & 1 & 1 & 1\end{array}$

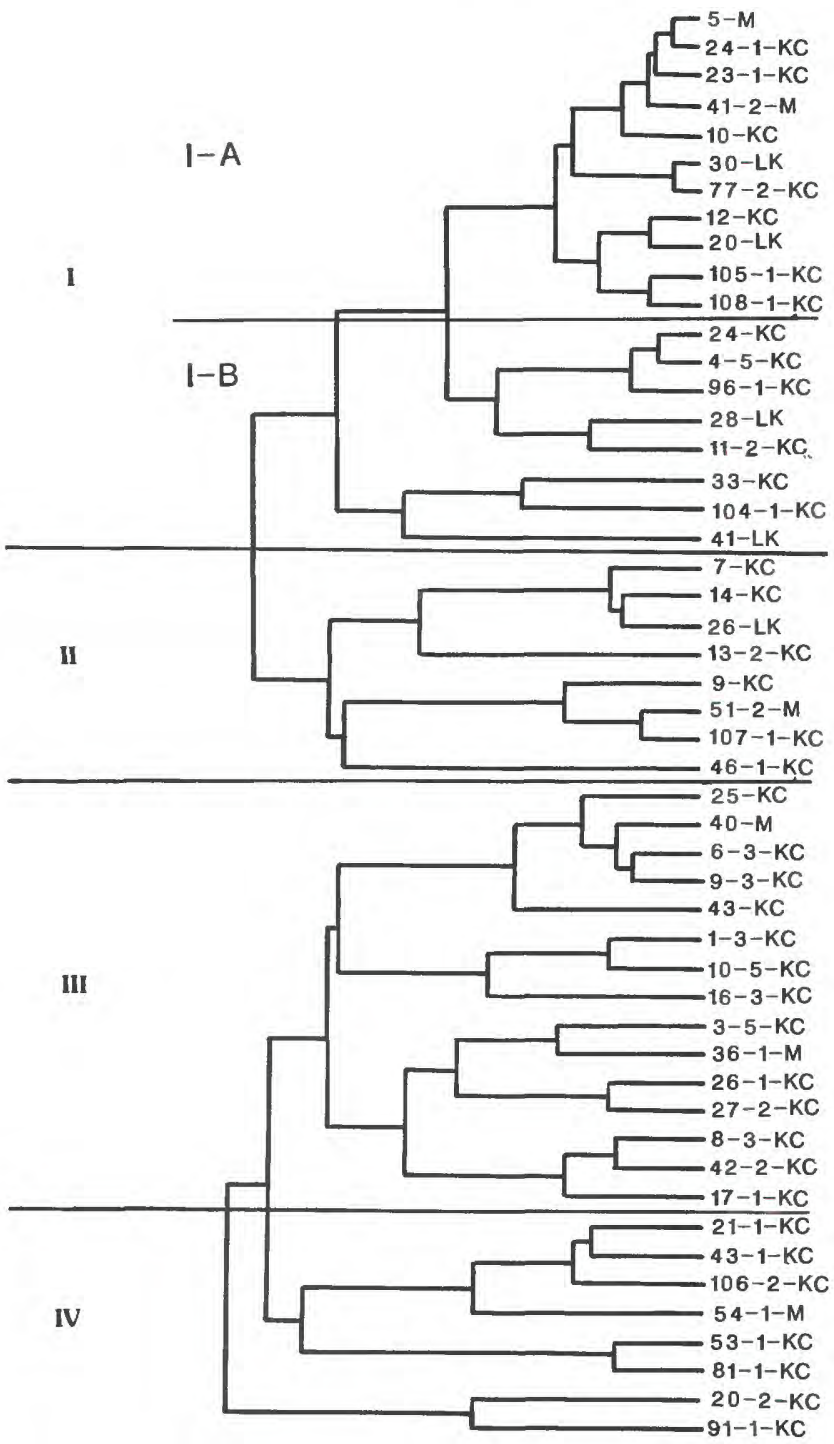

Figure 4. Weighted pair-group average dendrogram of framework grains for Desmoinesian sandstones. Petrofacies I and II are rich in monocrystalline quartz and contain rare rock fragments, whereas petrofacies III and IV are compositionally heterogeneous and contain variable amounts of all constituents. Sample numbers shown along right-hand margin. Detailed petrofacies descriptions are given in table 2; sample location and compositional data are given in Dyman (1987).

Petrofacies II sandstones are found throughout the Desmoinesian in all but the westernmost part of the study area. Petrofacies II is intermediate in composition between quartz-rich petrofacies I and quartz-poor petrofacies III and IV.
Table 2. Petrofacies sandstones in this study

summary for

[n, number of samples in each group. Mean and range given for framework constituents: Qm, monocrystalline quartz; Qp, polycrystalline quartz; Lt, total lithics; F, total feldspar]

\begin{tabular}{ccc}
\hline I $\quad(n=19)$ & $Q m=84$ & $78-98$ \\
& $Q p=5$ & $1-9$ \\
& $L t=4$ & $1-14$ \\
& $\mathrm{~F}=1$ & $0-3$
\end{tabular}

Samples widely distributed throughout Oklahoma; generally in lower Demoinesian Krebs Group. Two samples from Cabaniss Group (05 and 41-2). Subgroups I-A and I-B defined: I-A contains a mean of 88 percent Qm; I-B, 80 percent. Straight to slightly undulose quartz extinction. Trace of zircon and tourmaline.

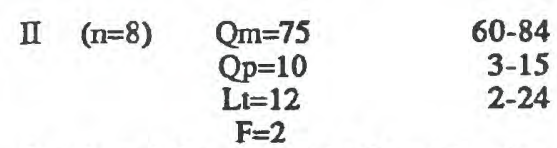

Distributed throughout the Desmoinesian and absent from only western part of study area. Straight to slightly undulose extinction. Trace of zircon, tourmaline, and homblende.

III $(n=15) \quad \begin{array}{cr}\mathrm{Qm}=60 & 49-74 \\ \mathrm{Qp}=13 & 7-22 \\ \mathrm{Lt}=21 & 11-37 \\ \mathrm{~F}=4 & 0-8\end{array}$

Compositionally heterogeneous group restricted to mid and upper Desmoinesian samples. Distributed throughout study area. Highest metamorphic rock fragments content in sample population (mean 9 percent). Contains sample $36-1$ (5 percent mica) and sample 17-1 (8 percent plagioclase). Variable quartz extinction. Trace of zircon, tourmaline, and homblende.

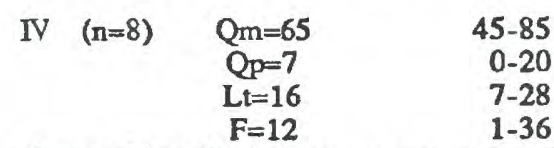

Compositionally heterogeneous upper Desmoinesian group, widely distribured throughout study area. Group includes two feldspar-rich samples (53-1, 81-1) from Oklahoma Panhandle and two limestone-rich samples (20-2, 91-1) from north and south parts of study area. Variable quartz extinction. Trace of zircon, tourmaline, and homblende.

\section{Petrofacies III}

Petrofacies III is compositionally heterogeneous, and, although it generally contains less than 70 percent monocrystalline quartz (mean 60 percent), values range from 49 to 74 percent (fig. 7). Polycrystalline quartz ranges from 7 to 22 percent and averages 13 percent. Petrofacies III is lithic rich (mean 21 percent) and metamorphic grains are the most abundant (mean 9 percent). Sandstones vary from those with abundant metamorphic and polycrystalline quartz grains (sample 40, Senora Formation, and sample 6-3, Red Fork sandstone) to those with abundant chert and metamorphic grains (sample 26-1, Red Fork sandstone, and sample 42-2, Bartlesville sandstone). Some samples 


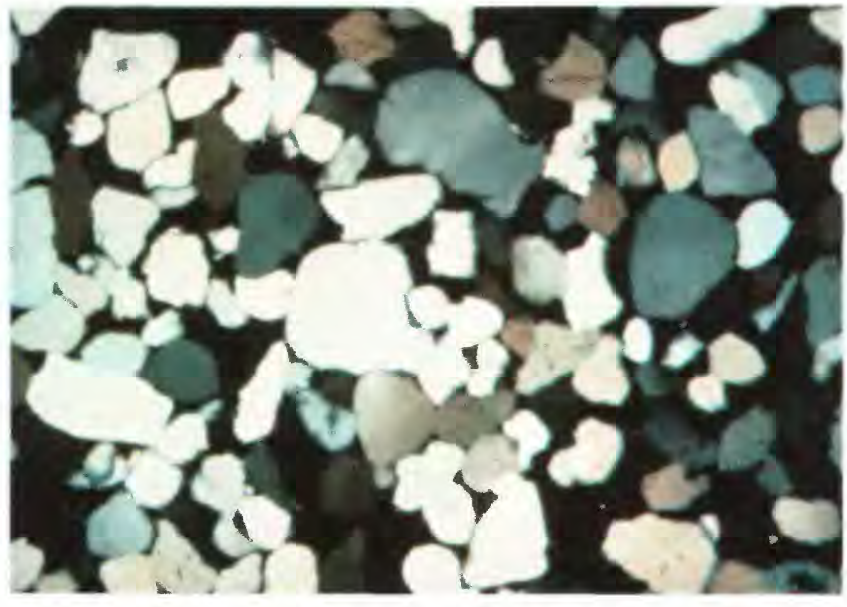

Figure 5. Petrofacies I sandstone. Red Fork sandstone, Gulf Oil Company No. 1 Sheik, sec. 25, T. 28 N., R. 1 E.; sample 24-1 taken at 3,605 ft. Quartzarenite $(3.0 \mathrm{~mm}$ across).

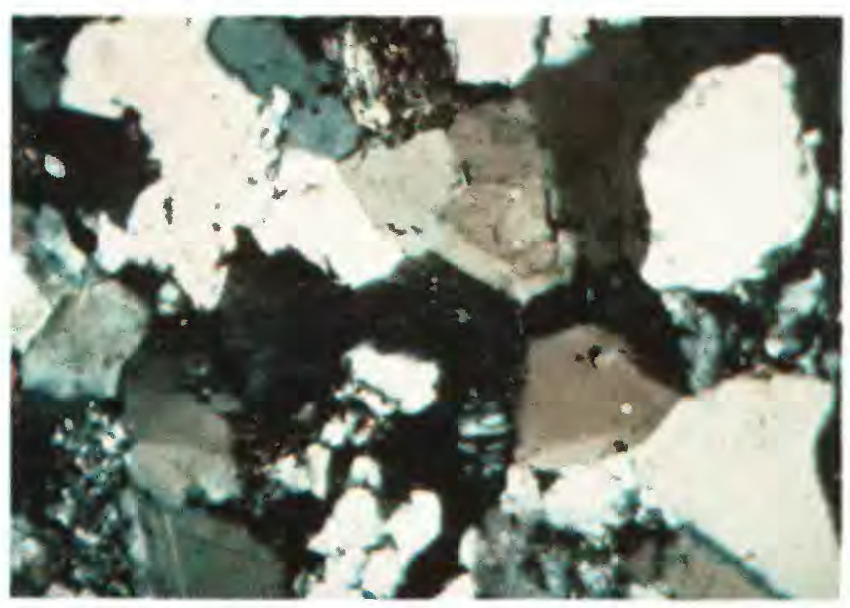

Figure 6. Petrofacies II sandstone. Red Fork sandstone, Indian Wells No. 4-24 Hajek, sec. 24, T. 28 N., R. 5 W.; sample 13-2 taken at 4,681 ft. Litharenite (3.0 $\mathrm{mm}$ across).

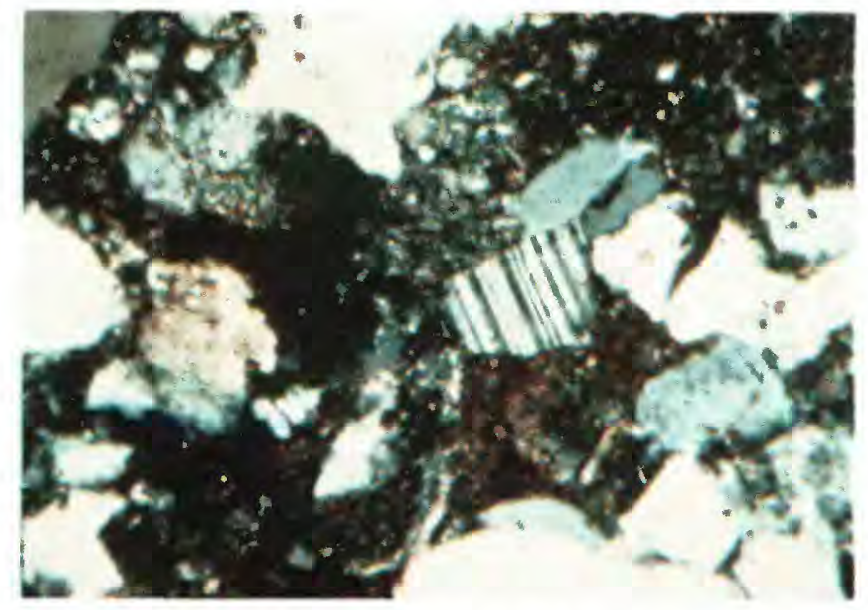

Figure 7. Petrofacies III sandstone. Red Fork sandstone, Davis Oil No. 1 Herbing, sec. 17, T. 14 N., R. 14 W.; sample $17-1$ taken at $10,916 \mathrm{ft}$. Litharenite (3.0 $\mathrm{mm}$ across). contain abundant plagioclase (sample $17-1,8$ percent, Red Fork sandstone) or mica (sample 36-1, 5 percent, Prue sandstone). Many compositionally intermediate forms exist.

Petrofacies III sandstones are found throughout the study area but are restricted to the middle and upper Desmoinesian. Sandstones from both petrofacies III and IV together form lithic-rich concentrations in eastern and western Oklahoma (fig. 3). Metamorphic-rich petrofacies III sandstones are abundant in the northwestcentral and eastern parts of Oklahoma.

\section{Petrofacies IV}

Petrofacies IV is also compositionally heterogeneous because cluster groups join at low levels of similarity. Petrofacies IV includes sandstones containing from 45 to 85 percent monocrystalline quartz (mean 65 percent). Polycrystalline quartz varies from 0 to 20 percent and averages 7 percent. Samples vary from those containing abundant potassium feldspar, from the Oklahoma Panhandle (samples 53-1 and 81-1, Cherokee Group; fig. 8), to those containing abundant limestone grains, from the northern and southern parts of the study area (sample 20-2, Red Fork sandstone, and sample 91-1, Deese Formation; fig. 9). Petrofacies IV samples are generally feldspar and lithic rich, and sedimentary rock grains are more abundant than metamorphic rock grains. Several plagioclase-bearing samples (sample 20-2, 5 percent, Red Fork sandstone) are in petrofacies IV. Many compositionally intermediate forms exist.

Petrofacies IV samples are widely distributed in Oklahoma but are restricted to middle and upper Desmoinesian strata.

\section{Factor-Score Maps}

The relative importance of each grain type in differentiating between sandstone samples cannot be graphically defined using cluster diagrams. Correspondence analysis factor-score maps were generated in order to: (1) corroborate the petrofacies subdivision identified by cluster analysis (Can the four petrofacies be recognized on the factor score maps?); (2) observe sample distribution in factor space (How are the samples compositionally related, what is the range in compositional variation, and what can be said about provenance?); and (3) identify variable influence for factor score groupings (How does each variable affects each sample?). Figures 10-12 are factor-score maps for the first four factors and incorporate the 10 framework grain types used in the cluster analysis.

Figure 10 is the factor-score map for factors 1 and 2. Sixty percent of the sample population variance 


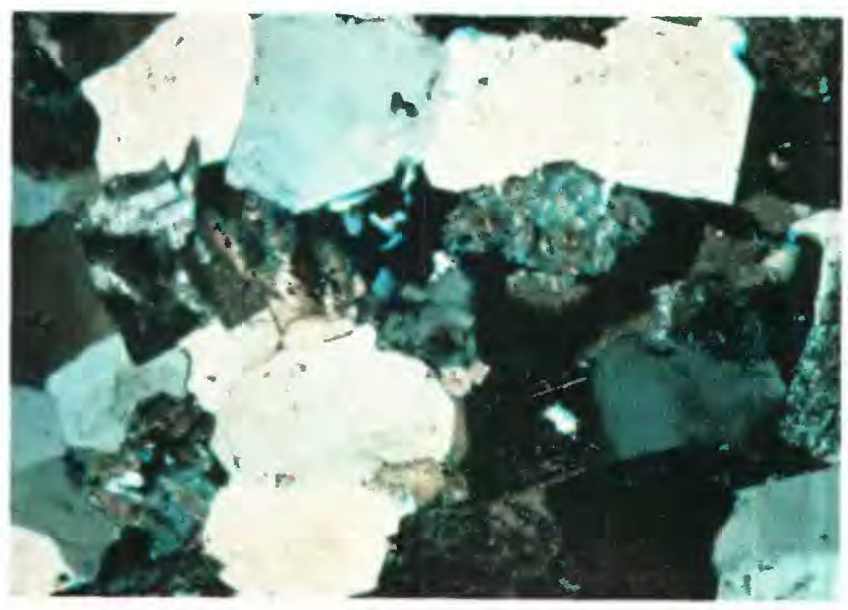

Figure 8. Petrofacies IV sandstone. Red Fork sandstone, Texaco No. 1 Hartley, sec. 33, T. 3 N., R. 10 E; ; sample 81-1 taken at $4,535 \mathrm{ft}$. Subarkose (3.0 mm across).

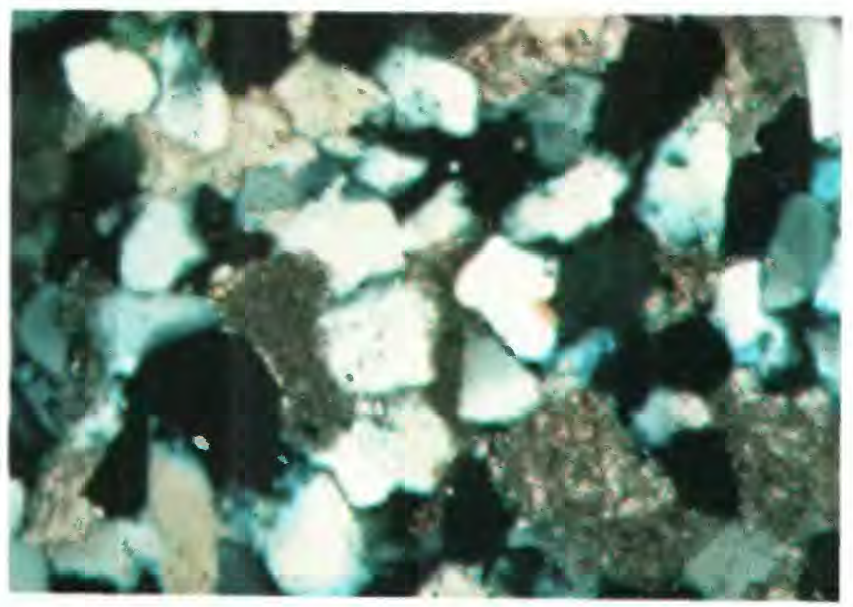

Figure 9. Petrofacies IV sandstone. Deese Group, BuckLeben No. 1 Harmon, sec. 8, T. 4 N., R. 1 W.; sample 91-1 taken at 5,467 ft. Litharenite ( $3.0 \mathrm{~mm}$ across).

contributed mostly by potassium feldspar, quartz, plagioclase, chert, and limestone and metamorphic grains is represented by the first two factors (table 1). The cluster of points in the lower left part of the diagram represents monocrystalline quartz-rich (variable 1) sandstones predominantly from petrofacies I and II (samples 5,10 , and 41-2). Monocrystalline quartz-rich sandstones in the lower part of the lower left also tend to contain metamorphic grains (sample 28, Warner Sandstone Member; variable 9), whereas sandstones in the upper part of the left tend to contain more potassium feldspar grains (sample 48-1, Bartlesville sandstone; variable 5).

The scattered array of points at the right center and top of the figure represents quartz-poor petrofacies III and IV sandstones from the middle and upper Desmoinesian. Samples 53-1 and 81-1 at the top of the diagram are the potassium feldspar samples from the Cherokee Group in the Oklahoma Panhandle. Sample
46-1 (Bartlesville sandstone, lower right; variable 8) is the only sample containing volcanic grains. Sample 26-1 (Red Fork sandstone) represents monocrystalline quartz-poor, polycrystalline quartz-rich (variable 2) petrofacies III and IV samples. The distribution of most points is gradational, and intermediate forms exist between clusters of samples.

Figure 11 is the factor-score map for factors 3 and 4 , which together contribute approximately 25 percent to the total variation in the sample population. This plot emphasizes sample differences resulting from the distribution of chert, mudstone-sandstone, monocrystalline and polycrystalline quartz, and limestone, and metamorphic grains. This plot is similar to the plot shown in figure 10 because the quartz-rich and quartz-poor petrofacies and the potassium feldspar-, volcanic-, and limestone-rich samples can be recognized. Because monocrystalline and polycrystalline quartz have lower loadings for factors 3 and 4, sample points are more centrally located on figure 11 and their lines are short.

The factor-score plot for factors 2 and 4 (fig. 12) reveals a greater spread of sample points because these two factors are not dominated by a single variable (for example, limestone or potassium feldspar) but instead contain higher loadings for several variables. Samples rich in metamorphic grains (samples 40 and 6-3, variable

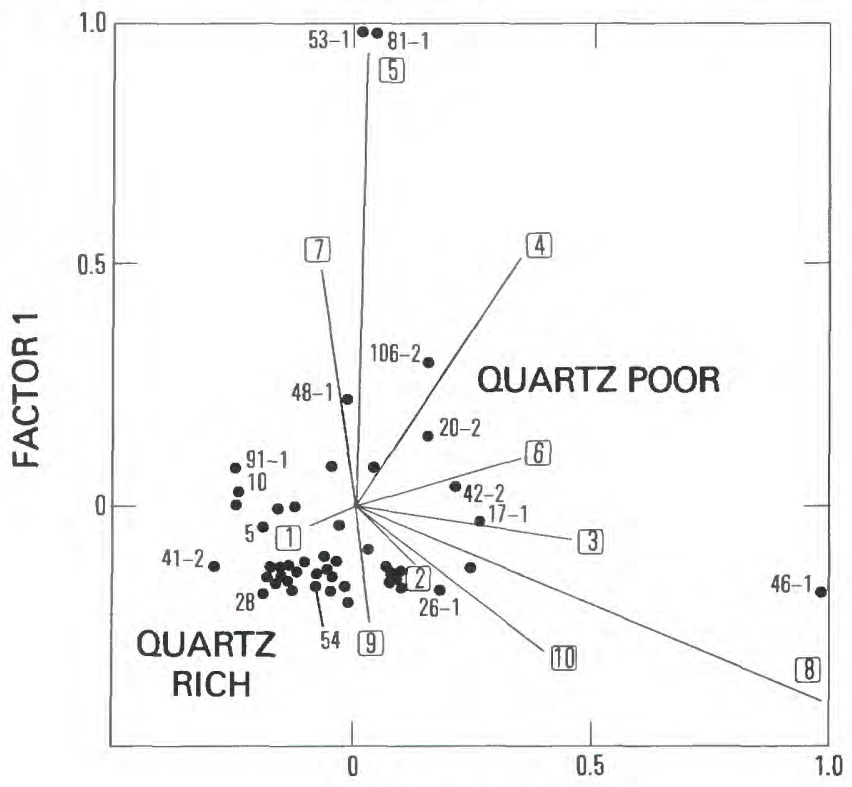

FACTOR 2

Figure 10. Correspondence analysis factor-score map, factors 1 and 2. Numbers in squares represent variable contributions in factor space where variable 1 is monocrystalline quartz, variable 2 is polycrystalline quartz, variable 3 is chert, variable 4 is plagioclase, variable 5 is potassium feldspar, variable 6 is mudstone-sandstone, variable 7 is limestone, variable 8 is volcanic, variable 9 is metamorphic, and variable 10 is mica. Sample location and identification shown in figure 3; factor loadings given in table 1. 


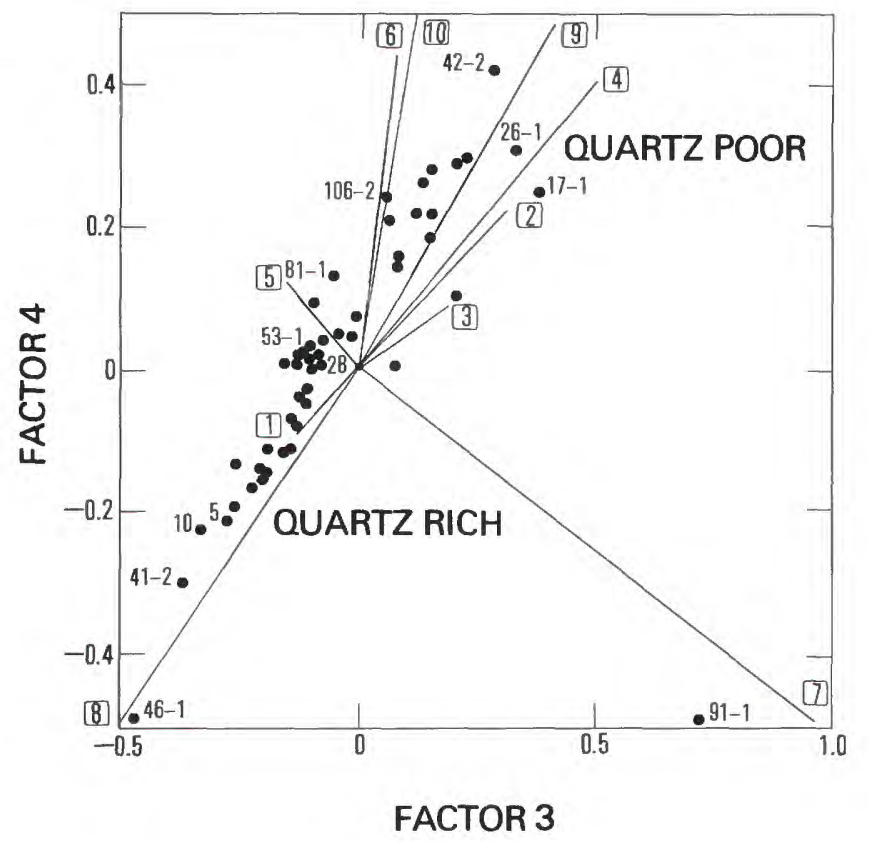

Figure 11. Correspondence analysis factor-score map, factors 3 and 4 . Numbers in squares represent variable contributions in factor space where variable 1 is monocrystalline quartz, variable 2 is polycrystalline quartz, variable 3 is chert, variable 4 is plagioclase, variable 5 is potassium feldspar, variable 6 is mudstone-sandstone, variable 7 is limestone, variable 8 is volcanic, variable 9 is metamorphic, and variable 10 is mica. Sample location and identification shown in figure 3; factor loadings given in table 1.

9) are well identified at the top of the figure because of the high loading for variable 9 in factor 4 . The greater spread in monocrystalline quartz-rich (petrofacies I and II) samples is due to minor variations in the contribution of chert, lithic, and feldspar grains.

Sample distribution patterns in factor space based on other combinations of factors (for example, factors 2 and 3 ) provide the same relationships presented here. The four petrofacies previously defined by using cluster analysis can be recognized using the correspondence analysis method. The variation in composition of sandstone samples based on the influence of each grain type is best illustrated, however, by using the correspondence analysis factor-score maps. The compositional limits defined for each plot represent the known compositional limits for Desmoinesian sandstones in this study.

\section{PALEOGEOGRAPHIC IMPLICATIONS}

A total quartz (Q)-total feldspar (F)-total lithics (L) plot (Dickinson and others, 1983) was prepared separately to verify and support the quantitative studies (fig. 13). QFL plots do not differentiate sandstones based on many variables but do support the quantitative

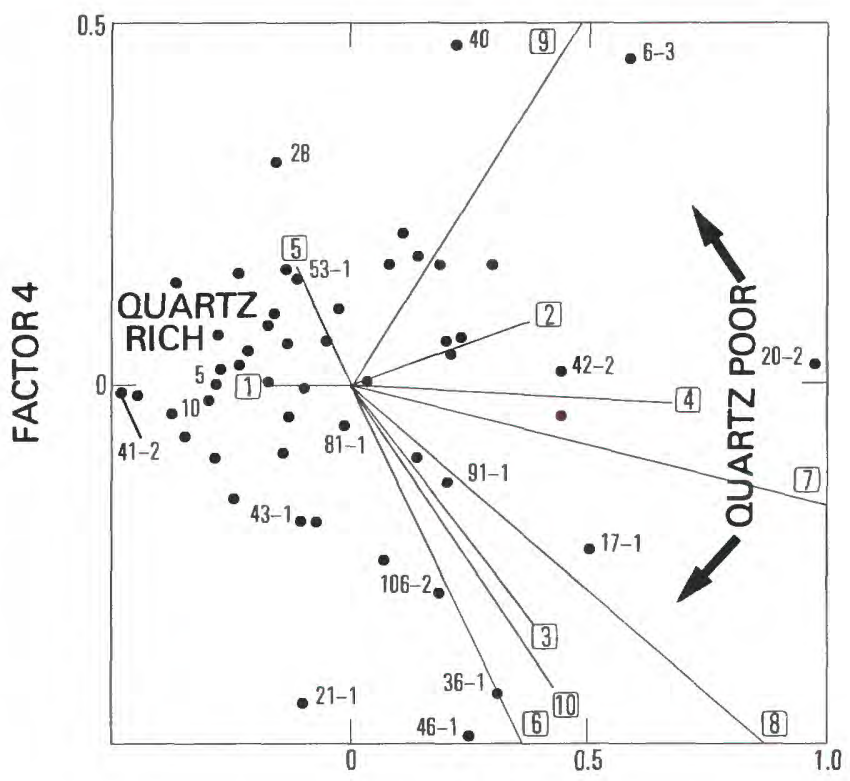

FACTOR 2

Figure 12. Correspondence analysis factor-score map, factors 2 and 4. Numbers in squares represent variable contributions in factor space where variable 1 is monocrystalline quartz, variable 2 is polycrystalline quartz, variable 3 is chert, variable 4 is plagioclase, variable 5 is potassium feldspar, variable 6 is mudstone-sandstone, variable 7 is limestone, variable 8 is volcanic, variable 9 is metamorphic, and variable 10 is mica. Sample location and identification shown in figure 3; factor loadings given in table 1.

studies. Early Desmoinesian (petrofacies I) sandstones were derived from craton interior (CI) continental block (cratonic shields and platforms) and recycled orogen (RO) terranes (collision orogens and foreland thrust belts), whereas middle and late Desmoinesian sandstones were derived from recycled orogen and transitional continental (TC) terranes (foreland continental blocks). Samples migrate toward the lithic pole from petrofacies I to IV.

Quantitative analyses in this study support the plate tectonic implications derived from the plot of Dickinson and others (1983) and indicate that Desmoinesian sandstones were derived from sedimentary, metamorphic, and granitic source areas (craton, orogenic belt, and batholith). Compositional trends from these quantitative analyses include the following:

1. Although compositional heterogeneity increases slightly upward from early to late Desmoinesian, some exceptions exist. The lower Desmoinesian Warner Sandstone Member and Hartshorne Sandstone are the most quartz rich but contain slightly less quartz westward in eastern Oklahoma. There is a change upward stratigraphically in eastern Oklahoma from Atokan, predominantly marine shelf sandstones to 


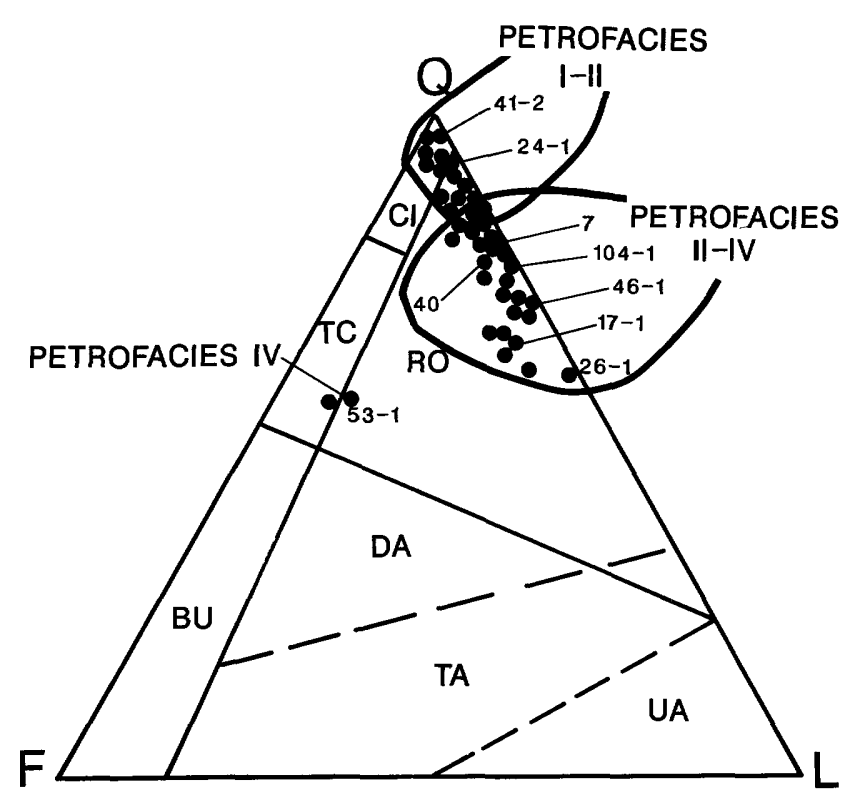

Figure 13. Total quartz (Q)-total feldspar (F)-total lithics (L) plot of Desmoinesian sandstones used in this study. $\mathrm{Cl}$, continental interior; TC, transitional continental; BU, basement uplift; RO, recycled orogen; DA, dissected arc; TA, transitional arc; UA, undissected arc. Methods and provenance boundaries from Dickinson and others (1983).

Desmoinesian, predominantly deltaic sandstones (O'Donnell, 1983). The central Oklahoma quartz-rich (petrofacies I) belt coincides in part with the Nemaha uplift. Adkison (1972) identified a north-trending sandstone-rich belt within the Ordovician Simpson Group in south-central Kansas. The north-trending quartz-rich belt may be related to these quartz-rich Simpson Group sandstone source areas; however, a thorough basin analysis should be conducted in order to fully define this trend.

2. Total lithics content is greatest (petrofacies III and IV) in two broadly defined north-trending belts in western and eastern Oklahoma. The total average lithic content of Desmoinesian sandstones is greatest in northern Oklahoma; available lithic detritus from southern sources may have been trapped in the deeper parts of the Anadarko, Ardmore, and McAlester basins. Hare (1970), however, recognized schistose metamorphic and shale fragments in the Thurman Sandstone and identified an Ouachita source for the Thurman Sandstone in Hughes and Coal Counties (southeast Oklahoma). Jacobson (1959) identified sedlitharenites rich in shale fragments in the Desmoinesian Deese Formation in the Ardmore basin and attributed these to unroofing of shales of the Mississippian and Pennsylvanian Springer Formation from the Arbuckle uplift. No change in the early to late Desmoinesian distribution of lithic grains was identified in this study.
3. Sandstones rich in limestone detritus are concentrated in two zones, one in northern Oklahoma and one in southern Oklahoma. Unroofing of lower Paleozoic carbonate terranes may have been greater in the Wichita-Criner and Arbuckle regions during the middle Desmoinesian (Tomlinson and McBee, 1959). Dunham (1955) identified limestone conglomerates and cherty, quartzose, and calcareous sandstones in the Deese Formation in the northern part of Murray County in southern Oklahoma. The northern Oklahoma sample may be related to lower Paleozoic carbonate source areas of the Nemaha and central Kansas uplifts. Additional samples must be analyzed before the influence of local limestone sources can be fully established.

4. Areas rich in polycrystalline quartz coincide in part with areas rich in monocrystalline quartz and areas rich in total lithic grains, but the relationship to provenance is not clear. Problems may exist in assigning polycrystalline grains to either sedimentary lithic grains or quartz.

5. The two arkosic sandstones from the Oklahoma Panhandle are related to western uplifts of the ancestral Rocky Mountains. Precambrian granitic basement rocks of the Arbuckle and eastern WichitaCriner uplifts were not a sediment source during the Desmoinesian. Feldspar-bearing samples in northeastern Oklahoma are probably related to cratonic source areas to the north and east.

\section{SUMMARY}

Correspondence and cluster analysis is very useful in understanding compositional variation and establishing petrofacies in highly variable sample populations such as the one used in this study.

Results from R-mode correspondence analysis indicate that the relative proportions of monocrystalline and polycrystalline quartz, chert, potassium and plagioclase feldspar, and limestone, metamorphic, and mudstone-sandstone grains best characterize Desmoinesian sandstones in the population of samples studied here. Mica and volcanic grains, however, are not important in differentiating sandstones.

Results from Q-mode cluster and correspondence analysis indicate that lower Desmoinesian sandstones (Krebs Group) are relatively homogeneous and rich in monocrystalline quartz and contain rare rock fragments (petrofacies I and II). Basal Desmoinesian quartz-rich sandstones are restricted to eastern Oklahoma. Middle to upper Desmoinesian sandstones (Cabaniss and Marmaton Groups) are compositionally heterogeneous (petrofacies III and IV) and are widely distributed throughout the State. Desmoinesian sandstones exhibit a slight upward increase in compositional heterogeneity. Source areas include the craton, foreland blocks of the 
Ancestral Rocky Mountains, and the orogenic terranes of southern Oklahoma. The broad north-trending quartzrich belt of the Desmoinesian coincides in part with the Nemaha trend and may have been derived from sandstone-rich beds within the Simpson Group.

\section{REFERENCES CITED}

Adkison, W.L., 1972, Stratigraphy and structure of Middle and Upper Ordovician rocks in the Sedgewick basin and adjacent areas, south and central Oklahoma: U.S. Geological Survey Professional Paper 702, 33 p.

Branson, C.C., 1961, Pennsylvanian System of the midcontinent, in Branson, C.C., ed., Pennsylvanian System in the United States: American Association of Petroleum Geologists, p. 431-460.

David, M., Campiglio, C., and Darling, R., 1974, Progresses in $\mathrm{R}$ - and $\mathrm{Q}$-mode analysis; correspondence analysis and its application to the study of geological processes: Canadian Journal of Earth Sciences, v. 11, p. 131-146.

David, M., Dagbert, M., and Beauchamin, Y., 1977, Statistical analysis in geology; correspondence analysis method: Colorado School of Mines Quarterly, v. 72, no. 1, 60 p.

Davis, J.C., 1973, Statistics and data analysis in geology: New York, John Wiley, 550 p. 1986, Statistics and data analysis in geology (2nd ed.): New York, John Wiley, 646 p.

Dickinson, W.R., Beard, L.S., Brackenridge, G.B., Erjavec, J.L., Ferguson, R.C., Inman, K.G., Knepp, R.A., Lindberg, F.A., and Ryberg, P.T., 1983, Provenance of North American Phanerozoic sandstones in relation to tectonic setting: American Association of Petroleum Geologists Bulletin, v. 94, p. 222-235.

Dickinson, W.R., and Suczek, C.A., 1979, Plate tectonics and sandstone compositions: American Association of Petroleum Geologists Bulletin, v. 63, p. 2164-2182.

Dunham, R.J., 1955, Pennsylvanian conglomerates, structure, and orogenic history of the Lake Classen area, Arbuckle Mountains, Oklahoma: American Association of Petroleum Geologists Bulletin, v. 39, p. 1-30.

Dyman, T.S., 1987, Petrographic data for Atokan through Virgilian sandstones in Oklahoma: U.S. Geological Survey Open-File Report 87-137, 15 p.

Ebanks, W.J., Jr., 1979, Correlation of Cherokee (Desmoinesian) sandstones of the Missouri-Kansas-Oklahoma tri- state area, in Hyne, N.J., ed., Pennsylvanian sandstones of the midcontinent: Tulsa Geological Society Special Publication 1, p. 295-312.

Evans, J.L., 1979, Major structural and stratigraphic features of the Anadarko basin, in Hyne, N.J., ed., Pennsylvanian sandstones of the midcontinent: Tulsa Geological Society Special Publication 1, p. 97-114.

Folk, R.F., 1968, Petrology of sedimentary rocks: Austin, Tex., Hemphill's, 170 p.

Frezon, S.E., and Dixon, G.H., 1975, Paleotectonic investigations of the Pennsylvanian System in the United States, Texas Panhandle and Oklahoma, in McKee, E.D., and Crosby, E.J., eds., Paleotectonic investigations of the Pennsylvanian System in the United States: U.S. Geological Survey Professional Paper 853, p. 177-196.

Hare, B.D., 1970, Petrology of the Thurman Sandstone (Desmoinesian), Hughes and Coal Counties, Oklahoma: The Compass, v. 48 , no. 1 , p. 45-55.

Jacobson, L., 1959, Petrology of Pennsylvanian sandstones and conglomerates of the Ardmore basin: Oklahoma Geological Survey Bulletin 79, 139 p.

Johnson, K.S., 1971, Geologic fieldtrips in Oklahoma, Book I-Introduction, guidelines, and geologic history: Oklahoma Geological Survey Educational Publication 2, $15 \mathrm{p}$.

Jordan, L., 1957, Subsurface stratigraphic names of Oklahoma: Oklahoma Geological Survey Guidebook 6, 220 p.

Kluth, C.F., and Coney, P.J., 1981, Plate tectonics of the ancestral Rocky Mountains: Geology, v. 9, p. 10-15.

Krumme, G.W., 1981, Stratigraphic significance of limestones of the Marmaton Group (Pennsylvanian, Desmoinesian) in eastern Oklahoma: Oklahoma Geological Survey Bulletin 131, 67 p.

Luza, K.V., 1978, Regional seismic and geologic evaluations of Nemaha uplift, Oklahoma, Kansas, and Nebraska: Oklahoma Geology Notes, v. 30, no. 2, p. 49-60.

O'Donnell, M.R., 1983, Regressive shelf deposits in the Pennsylvanian Arkoma basin, Oklahoma and Kansas: Shale Shaker, v. 33, p. 23-37.

Sutherland, P.K., 1982, Lower and Middle Pennsylvanian stratigraphy in south-central Oklahoma: Oklahoma Geological Survey Field Conference Guidebook 20, 44 p.

Tomlinson, C.W., and McBee, W., 1959, Pennsylvanian sediments and orogenies of the Ardmore district, Oklahoma, in Petroleum geology of southern Oklahoma, volume II: American Association of Petroleum Geologists, p. 3-52. 


\section{Perlodicals}

Earthquakes \& Volcanoes (issued bimonthly).

Preliminary Determination of Epicenters (issued monthly).

\section{Technical Books and Reports}

Professional Papers are mainly comprehensive scientific reports of wide and lasting interest and importance to professional scientists and engineers. Included are reports on the results of resource studies and of topographic, hydrologic, and geologic investigations. They also include collections of related papers addressing different aspects of a single scientific topic.

Bulletins contain significant data and interpretations that are of lasting scientific interest but are generally more limited in scope or geographic coverage than Professional Papers. They include the results of resource studies and of geologic and topographic investigations; as well as collections of short papers related to a specific topic.

Water-Supply Papers are comprehensive reports that present significant interpretive results of hydrologic investigations of wide interest to professional geologists, hydrologists, and engineers. The series covers investigations in all phases of hydrology, including hydrogeology, availability of water, quality of water, and use of water.

Circulars present administrative information or important scientific information of wide popular interest in a format designed for distribution at no cost to the public. Information is usually of short-term interest.

Water-Resources Investigations Reports are papers of an interpretive nature made available to the public outside the formal USGS publications series. Copies are reproduced on request unlike formal USGS publications, and they are also available for public inspection at depositories indicated in USGS catalogs.

Open-File Reports include unpublished manuscript reports, maps, and other material that are made available for public consultation at depositories. They are a nonpermanent form of publication that may be cited in other publications as sources of information.

\section{Maps}

Geologic Quadrangle Maps are multicolor geologic maps on topographic bases in 7 1/2-or 15-minute quadrangle formats (scales mainly $1: 24,000$ or $1: 62,500$ ) showing bedrock, surficial, or engineering geology. Maps generally include brief texts; some maps include structure and columnar sections only.

Geophysical Investigations Maps are on topographic or planimetric bases at various scales; they show results of surveys using geophysical techniques, such as gravity, magnetic, seismic, or radioactivity, which reflect subsurface structures that are of economic or geologic significance. Many maps include correlations with the geology.

Misceilaneous Investigations Series Maps are on planimetric or topographic bases of regular and irregular areas at various scales; they present a wide variety of format and subject matter. The series also includes 71/2-minute quadrangle photogeologic maps on planimetric bases which show geology as interpreted from aerial photographs. Series also includes maps of Mars and the Moon.
Coal Investigations Maps are geologic maps on topographic or planimetric bases at various scales showing bedrock or surficial geology, stratigraphy, and structural relations in certain coal-resource areas.

Oil and Gas Investigations Charts show stratigraphic information for certain oil and gas fields and other areas having petroleum potential.

Miscellaneous Field Studies Maps are multicolor or black-andwhite maps on topographic or planimetric bases on quadrangle or irregular areas at various scales. Pre-1971 maps show bedrock geology in relation to specific mining or mineral-deposit problems; post-1971 maps are primarily black-and-white maps on various subjects such as environmental studies or wilderness mineral investigations.

Hydrologic Investigations Atlases are multicolored or black-andwhite maps on topographic or planimetric bases presenting a wide range of geohydrologic data of both regular and irregular areas; principal scale is $1: 24,000$ and regional studies are at $1: 250,000$ scale or smaller.

\section{Cataiogs}

Permanent catalogs, as well as some others, giving comprehensive listings of U.S. Geological Survey publications are available under the conditions indicated below from the U.S. Geological Survey, Books and Open-File Reports Section, Federal Center, Box 25425, Denver, CO 80225. (See latest Price and Availability List.)

"Publications of the Geological Survey, 1879-1961" may be purchased by mail and over the counter in paperback book form and as a set of microfiche.

"Publications of the Geological Survey, 1962-1970" may be purchased by mail and over the counter in paperback book form and as a set of microfiche.

"Publications of the U.S. Geological Survey, 1971- 1981" may be purchased by mail and over the counter in paperback book form (two volumes, publications listing and index) and as a set of microfiche.

Supplements for $1982,1983,1984,1985,1986$, and for subsequent years since the last permanent catalog may be purchased by mail and over the counter in paperback book form.

State catalogs, "List of U.S. Geological Survey Geologic and Water-Supply Reports and Maps For (State)," may be purchased by mail and over the counter in paperback booklet form only

"Price and Availability List of U.S. Geological Survey Publications," issued annually, is available free of charge in paperback booklet form only.

Selected copies of a monthly catalog "New Publications of the U.S. Geological Survey" available free of charge by mail or may be obtained over the counter in paperback booklet form only. Those wishing a free subscription to the monthly catalog "New Publications of the U.S. Geological Survey" should write to the U.S. Geological Survey, 582 National Center, Reston, VA 22092.

Note.--Prices of Government publications listed in older catalogs, announcements, and publications may be incorrect. Therefore, the prices charged may differ from the prices in catalogs, announcements, and publications. 

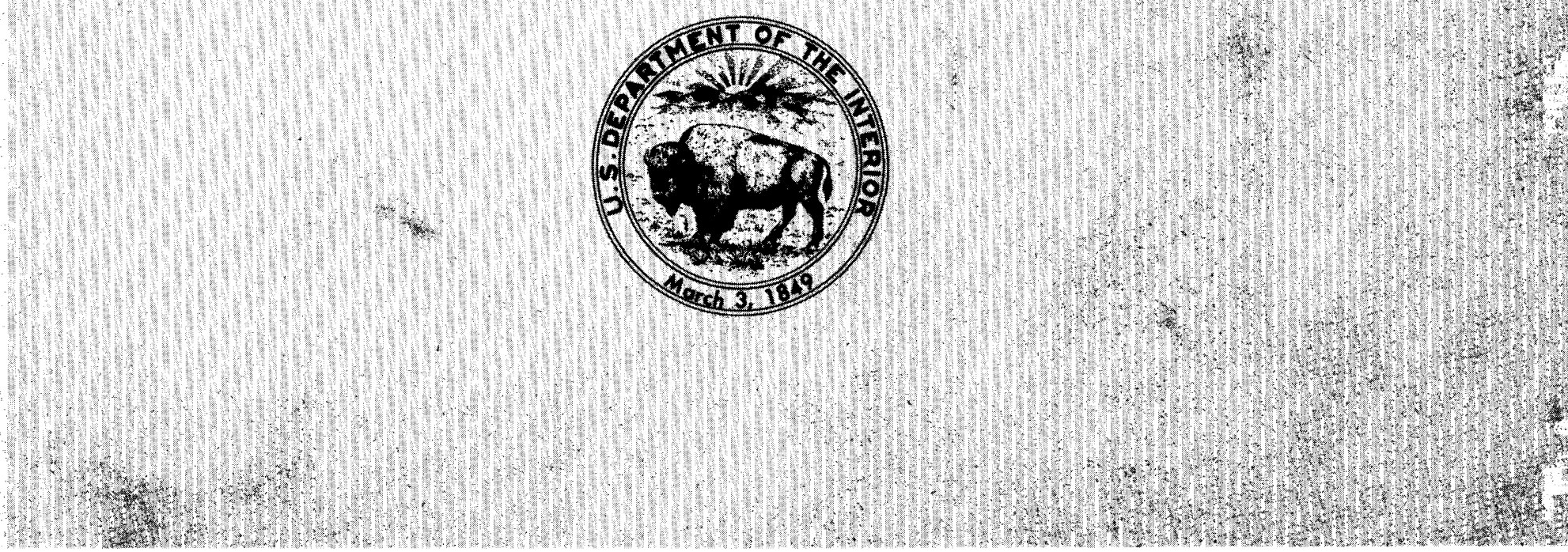